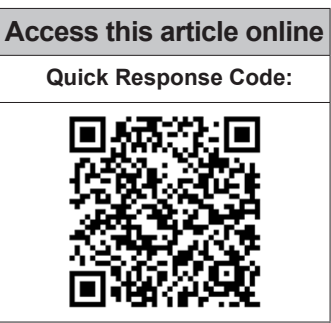

Website:

www.jponline.org

DOI:

10.4103/JLP.JLP_150_18
Department of Bioinformatics and

Biotechnology, International Islamic

University, Islamabad, ${ }^{1}$ Safe Blood Transfusion

Programme, Ministry of National Health Services, Government of Pakistan, Islamabad, ${ }^{2}$ Department of Pathology and Blood Bank, Shaheed Zulfiqar Ali Bhutto Medical University, Islamabad, ${ }^{3}$ Department of Pathology and Transfusion Medicine, District Headquarter Hospital, Mandi Bahauddin, Pakistan

Address for correspondence: Dr. Usman Waheed, Safe Blood Transfusion Programme, Ministry of National Health Services, Islamabad, Pakistan.

E-mail: usman. waheed07@gmail.com

Submission: 11-11-2018 Accepted: 22-03-2019

\title{
Molecular epidemiology of hepatitis B virus genotypes in blood donors in Islamabad, Pakistan
}

\author{
Iram Masood, Usman Waheed ${ }^{1,2}$, Muhammad Arshad, Muhammad Saeed ${ }^{3}$, \\ Ahmad Farooq, Sadaf Moneeba, Nosheen Basharat, Hasan Abbas Zaheer ${ }^{1,2}$
}

\section{Abstract:}

BACKGROUND: Hepatitis B virus (HBV) is a major causative agent of early, severe and prolonged liver infection that subsequently leads to cirrhosis of liver and hepatocellular carcinoma. The aim of this study was to evaluate the molecular epidemiology of hepatitis B virus (HBV) genotypes and comparison of serological assay performance versus polymerase chain reaction (PCR) in HBV screening.

METHODS: Blood samples of 8517 healthy blood donors were collected during the period of January to June 2017 from Blood Bank of Shaheed Zulfiqar Ali Bhutto Medical University, Islamabad. Samples were screened for HBsAg assay using technique of chemiluminescence immunoassay. PCR of positive samples was carried out using already reported genotype-specific primers by Naito et al. (2001). The results were confirmed by visualizing genotype bands.

RESULTS: The study confirmed the presence of HBV in $2.5 \%$ of blood donors, and PCR confirmed the presence of HBV-DNA in 92 samples. The genotyping was done by PCR using type-specific primer sequences. PCR was dogged to check six genotypes, i.e., A, B, C, D, E, and F. The results of this study show high levels of Genotype $\mathrm{D}$ is this region, i.e., $52.17 \%$ with less dominating Genotype $\mathrm{C}$, which is $16.30 \%$ with decreasing ratio of Genotype E (14.13\%), Genotype A and B (9.78\%), and mixed $D+E(2.17 \%)$. The presence of coinfection is found at lowest rate. Due to the high percentage of $\mathrm{HBV} / \mathrm{D}$, it is concluded that $\mathrm{D}$ genotype is common in our population.

CONCLUSION: The most prevalent HBV genotype in ICT region was genotype $\mathrm{D}$, which is responsible for liver cirrhosis and hepatocellular carcinoma. Efficacy of drugs varies with variation in genotypes of hepatitis B virus and also with geographical distribution.

Key words:

Genotypes, hepatitis B virus, Islamabad Central Territory, molecular epidemiology, treatment

\section{Introduction}

Bthe lood safety is a serious issue all over the world because of TransfusionTransmitted Infections (TTI's). Whole blood is screened before transfusion for five TTI makers, i.e., hepatitis B virus (HBV), hepatitis $\mathrm{C}$ virus (HCV), $\mathrm{HIV}$, malaria, and syphilis. In 2011, the WHO reported that the global seroprevalence of $\mathrm{HBV}, \mathrm{HCV}$,

This is an open access journal, and articles are distributed under the terms of the Creative Commons Attribution-NonCommercial-ShareAlike 4.0 License, which allows others to remix, tweak, and build upon the work non-commercially, as long as appropriate credit is given and the new creations are licensed under the identical terms.

For reprints contact: reprints@medknow.com
HIV, malaria, and syphilis in blood donors were $2.2 \%, 3.9 \%, 0.01 \%, 0.6 \%$, and $0.1 \%$, respectively. ${ }^{[1]} \mathrm{HBV}$ infection is a major health problem, and more than 350 million of the world population is the chronic carriers of the virus. ${ }^{[2]} \mathrm{HBV}$ is a member of hepadnaviridae family. It has circular genome of about $3200 \mathrm{bp}$. The DNA of HBV is double stranded, which has one complete strand, but other one is partial. Infectious particle of HBV is called Dane particle and is $42 \mathrm{~nm}$ in size. Basically, it has an outer envelope of HBsAg and nucleocapsid of

\footnotetext{
How to cite this article: Masood I, Waheed $U$, Arshad M, Saeed M, Farooq A, Moneeba S, et al. Molecular epidemiology of hepatitis $B$ virus genotypes in blood donors in Islamabad, Pakistan. J Lab Physicians 2019;11:240-3.
} 
$\mathrm{HBcAg}$ of $27 \mathrm{~nm}$ diameter having genome and DNA polymerase. ${ }^{[3]} \mathrm{HBV}$ is not able to cause any pathogenic effect till it finds a host, as host's immune system act as its accelerator. ${ }^{[4]}$

Over 1 million people die annually from primary adverse outcomes such as hepatocellular carcinoma (HCC) and cirrhosis. ${ }^{[5]} \mathrm{HBV}$ is transmitted percutaneously, sexually, and perinatally ${ }^{[6]}$ As a general rule, in high-prevalence countries (e.g., Asia), the source of infection is mainly through perinatal transmission from chronically infected mothers. In low-prevalence countries (e.g., western countries), infection occurs mainly by sexual contacts and percutaneously, for example, by needle sharing among injecting drug users. ${ }^{[7]}$ Symptoms of infection start to appear after 90 days of exposure, but in some cases, they can appear before time. ${ }^{[8]}$ In the acute phase of infection, symptoms may not appear in many individuals, while some may experience vomiting, dark urine, nausea, fatigue, vomiting, and yellowish eyes and skin (jaundice). ${ }^{[9]}$ Rates of HBV infections are very high in underdeveloped countries like Pakistan with 9 million people infected with this deadly virus. ${ }^{[10]}$ The failure in tackling the infection has been related to the high cost of antiviral drugs, lack of vaccination and public awareness about infection, and the mismanagement to address the problem in Pakistan. ${ }^{[11]}$

Evolutionary changes take place in HBV genotype which changes disease pattern such as its intensity and development which is due to different stimuli including viral load, specific viral mutations, and emerging genotypes. ${ }^{[12]} \mathrm{HBV}$ sequence is characterized by $>8 \%$ nucleotide differences for genotype, and $4 \%-8 \%$ nucleotide differences for subgenotype. Many genotypes and subgenotypes of HBV have been discovered from time to time. ${ }^{[13]}$

HBV replicates its DNA genomes by reverse transcription of an RNA intermediate. ${ }^{[14]} \mathrm{HBV}$ polymerase uses the viral pregenomic RNA as template to synthesize minus-strand viral DNA by RNA-dependent DNA polymerase. This strand is then used to synthesize plus-strand DNA. ${ }^{[15]}$ HBV reverse transcriptase does not have a proofreading activity, therefore, many HBV genotypes, subgenotypes, mutants, and recombinants emerge. ${ }^{[12]}$

Infections during acute phase resolve unexpectedly after short period while in chronic type, treatment is necessary. Certified and approved treatment is possible by the use of interferon, adefovir, and lamivudine. ${ }^{[16]}$ Approximately $20 \%$ individuals which go through interferon therapy show low levels of HBeAg in serum. ${ }^{[17]}$ Interferon varies in its response to HBeAg seroconversion with respect to $\mathrm{HBV}$ genotypes, whereas such correlation among genotypes and to lamivudine or adefovir dipivoxil therapy has not been demonstrated. Hence, it is assumed that genotype is an important factor in the progression of disease and to make a better strategy of treatment. ${ }^{[18]}$

The presence of virus in serum can be directly tested by its biochemical, histological, and virological characteristics such as alanine aminotransferase levels and presence or absence of HBV linked antigens and antibodies. Sometimes, biopsy of liver is also necessary for confirmation of disease, to check disease progression, and inflammation of liver. ${ }^{[19]}$ With the emergence of resistant viral mutants, there is a need for developing new improved molecular assays for diagnosis, treatment, and therapy. In this scenario, genotyping systems using restriction fragment length polymorphism (RFLP) analysis of S-gene polymerase chain reaction (PCR) product or pre-S sequence has previously been reported. ${ }^{[20]}$ Various methods have been used for genotyping including RFLP, sequencing, PCR with genotype-specific primers, real-time PCR, or line probe assay. All these methods vary in their accuracy. ${ }^{[21]}$

This study was designed to evaluate the prevalence of HBV genotypes in Islamabad Central Territory region of Pakistan, to evaluate the serological assay performance versus the PCR screening in blood centers and to assist in drug therapy based on the information of the genotypes prevalence.

\section{Materials and Methods}

Study protocols were approved from the institutional ethical board. Blood samples of 8517 healthy blood donors were collected during the period of January to June 2017 at Shaheed Zulfiqar Ali Bhutto Medical University, PIMS Hospital Blood Bank Islamabad, Pakistan. After collection of blood sample, tubes were left at room temperature for $30 \mathrm{~min}$. The samples were then centrifuged at $14,000 \mathrm{rpm}$ for $5 \mathrm{~min}$. Two clear layers were formed, i.e., pellet having red blood cell and supernatant having antigens and antibodies in the serum. The resulting supernatant was utilized for further serological testing. Samples were screened for HBsAg assay using chemiluminescence immunoassay (ARCHITECT i2000SR Immunoassay Analyzer, Abbott Diagnostics, USA). Extraction of DNA was done from $100 \mu \mathrm{l}$ serum sample, using standard protocol of Sambrook and Russel (2001). Later, PCR of positive samples was carried out using already reported genotype-specific primers by Naito et al. (2001). Reaction mixture was $50 \mu \mathrm{l}$, containing $1 \times$ buffer, $1.5 \mathrm{U}$ Taq polymerase, $20 \mu \mathrm{M}$ primers, and $2.4 \mu \mathrm{M}$ dNTPs. Forty cycles were run for $1 \mathrm{~min}$ at 


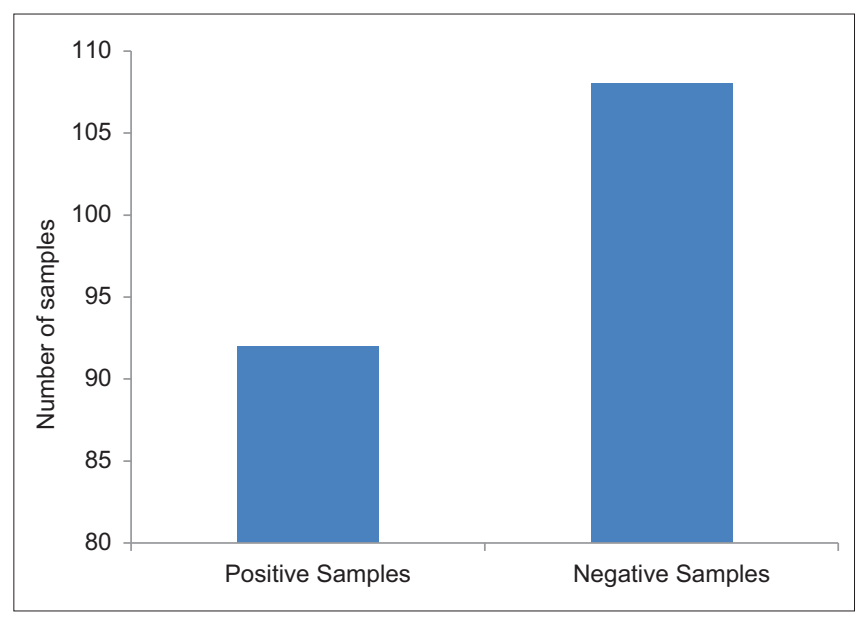

Figure 1: Graphical representation of samples tested for the presence of hepatitis $B$ virus DNA

$95^{\circ} \mathrm{C}, 30 \mathrm{~s}$ at $50^{\circ} \mathrm{C}$, and $30 \mathrm{~s}$ at $72^{\circ} \mathrm{C}$. The amplified end product was run on $2.0 \%$ agarose gel and visualized under ultraviolet illuminator. Later, the results were confirmed by visualizing genotype bands. The expected sizes of genotypes were as followed Genotype A - 67-kb, B - 259-kb, C - 100-kb, D - 99-kb, $\mathrm{E}-123-\mathrm{kb}, \mathrm{F}-50-\mathrm{kb}$.

\section{Results}

Of 8517 samples, 200 showed the presence of HBsAg in serum. Further PCR of 200 samples was done to confirm the presence of HBV DNA. The expected size of HBV DNA in running ladder was $2 \mathrm{~kb}$. PCR confirms the presence of HBV DNA in 92 samples [Figure 1].

Later genotyping was done by PCR using type-specific primer sequences. PCR analysis was done to check six HBV genotypes, i.e., A, B, C, D, E, and F. The results of this study show high levels of Genotype D in the city, i.e., $52.17 \%$ with less dominating Genotype C, which is $16.30 \%$ with decreasing ratio of genotype $\mathrm{E}(14.13 \%)$, Genotype A and B (9.78\%), and mixed D + E (2.17\%). The presence of coinfection is found at lowest rate [Figure 2].

\section{Discussion}

During the execution of the current research study, genotyping of the HBV was accomplished. Samples were taken from Blood Bank, PIMS, Islamabad. This molecular epidemiology study describes HBV genotypes in blood donors in Islamabad Capital Territory, Pakistan. Blood donors are considered as healthiest pool of the nation. Although vaccination of many of individuals for $\mathrm{HBV}$ is done in childhood, still there are chances to get this infection.

HBV genotypes have impact on treatment, and they show different results of drug efficacy. Commonly used therapy

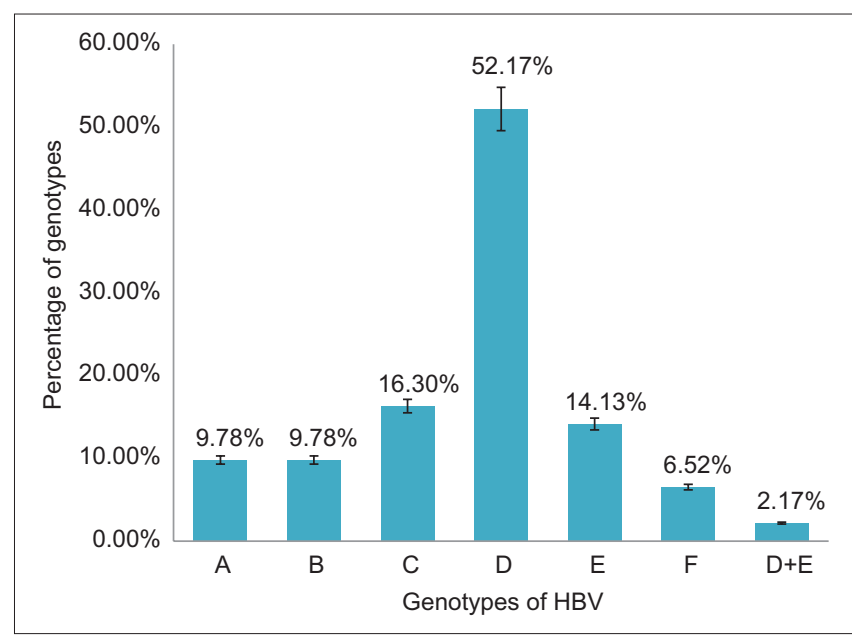

Figure 2: Prevalent genotypes of hepatitis B virus in Islamabad Capital Territory

against $\mathrm{HBV}$ is interferon alpha treatment, and after that, pegylated interferons are given. These drugs stop replication of virus and clear the HBsAg and $\mathrm{HBeAg}$ from serum, i.e., seroclearence. However, interferon treatment shows poor response against HBV in case of Genotype D, which is dominating genotype in this region. Interferon therapy does not show complete seroclearence of HBsAg and HBeAg in case of Genotype D. The predominance of HBV Genotype D in the ICT region indicates that the majority of these individuals cannot get benefit from interferon therapy.

Although the vaccination of $\mathrm{HBV}$ is available and recommended in immunization course of children, still there are chances to get this infection. ${ }^{[12]}$ A study at molecular level in China showed higher rate of $\mathrm{HBV}$ infection in healthy blood donors who were $14.4 \%$ among which $80 \%$ infections were of Genotype C. High percentage of deletion mutants in pre S1/S2 gene was found. This genotype was also linked with HCC, which was an alarming situation. ${ }^{[22]}$ In Brazil, the ratio of Genotype A was $48.5 \%$, and its subgenotype A1 was $90.2 \%$, Genotype D was $84.2 \%$ in South, and $47.6 \%$ in Central regions, whereas the frequency of Genotype F was low $(13 \%)$ with its isolates. ${ }^{[23]}$ While in another study in Thailand proves that Genotype $\mathrm{C}$ ratio was relatively higher $(89.3 \%)$ than Genotype B $(7.4 \%)$, Genotype A $(0.5 \%)$, while the Genotype 4 sera could not be identified. ${ }^{[24]}$

In Pakistan, several studies have been conducted. Screening of healthy individuals was done at National Institute of Health, Islamabad by EIA and genotyping by multiplex PCR using type-specific primers. About $64 \%$ males and 36\% females were enrolled. High proportion of Genotype D (65.34\%) was found with decreasing ratio of A (4.95\%) and B (26.73\%). ${ }^{[25]}$ While screening of healthy females at two universities in Karachi showed that 150 samples out 180 HBsAg have 
Genotype D, 29 displayed coinfection of Genotypes $\mathrm{B}$ and D, and 1 exhibited coinfection of Genotypes C and D. ${ }^{[26]}$

\section{Conclusion}

This study was designed to check the prevalence of HBV genotypes in Islamabad. Our results indicate that Genotype D is the predominant genotype in this area. Genotype D is responsible for liver cirrhosis and HCC. This study is the first to report the presence of Genotype D in blood donors in Islamabad, Pakistan. This is a significant step as interferon treatment does not show enough response against Genotype D, and the efficacy of drugs varies with variation in genotypes of $\mathrm{HBV}$ and also with geographical distribution. So before treatment, complete knowledge of HBV genotypes is required to start a beneficial and efficient treatment. There is also a need to design drugs on the basis of genotypes. This will save time, money, and lives of people. Furthermore, there is also a need to improve our health condition, socioeconomic condition, and awareness about viral infections, especially in remote areas.

Prevention of HBV transmission can be made possible by proper screening of blood donations in order to control infectious diseases. Proper counseling and vaccination of infants and of individuals who are at high risk is the need of the day. The threat of transmission of HBV from infected mother to adolescent can be reduced by administration of Hepatitis B immune globulin and HBV vaccine. ${ }^{[27]}$

\section{Financial support and sponsorship}

Nil.

\section{Conflicts of interest}

There are no conflicts of interest.

\section{References}

1. Zaheer HA, Waheed U. Blood safety system reforms in Pakistan. Blood Transfus 2014;12:452-7.

2. Kao JH, Wu NH, Chen PJ, Lai MY, Chen DS. Hepatitis B genotypes and the response to interferon therapy. J Hepatol 2000;33:998-1002.

3. Ahad MA, Alim MA. Current challenges in hepatitis B. J Teach Assoc 2006;19:38-44.

4. Grimm D, Thimme R, Blum HE. HBV life cycle and novel drug targets. Hepatol Int 2011;5:644-53.

5. Kim BK, Revill PA, Ahn SH. HBV genotypes: Relevance to natural history, pathogenesis and treatment of chronic hepatitis B. Antivir Ther 2011;16:1169-86.

6. Dienstag JL. Hepatitis B virus infection. N Eng1 J Med
2008;359:1486-500.

7. Thimme R, Blum HE. Therapy of hepatitis B. Praxis (Bern 1994) 2006;95:1383-8.

8. Availablefrom:http://www.cdc.gov.[Lastretrieved on2017Oct23].

9. Available from: http://www.who.int/en/. [Last retrieved on 2017 Jul 15].

10. Ali M, Idrees M, Ali L, Hussain A, Ur Rehman I, Saleem S, et al. Hepatitis B virus in Pakistan: A systematic review of prevalence, risk factors, awareness status and genotypes. Virol J 2011;8:102.

11. Hanif M, Zaidi P,Habib S, Ahmed A, Raza A, Ahmed S, et al. Study of genotypes and subgenotypes of Hepatitis B virus prevalent in big cities of Pakistan. Afr J Microbiol Res 2013;7:152-7.

12. Sunbul M. Hepatitis B virus genotypes: Global distribution and clinical importance. World J Gastroenterol 2014;20:5427-34.

13. Cooksley WG. Do we need to determine viral genotype in treating chronic hepatitis B? J Viral Hepat 2010;17:601-10.

14. Wang GH, Seeger C. The reverse transcriptase of hepatitis B virus acts as a protein primer for viral DNA synthesis. Cell 1992;71:663-70.

15. Jones SA, Hu J. Hepatitis B virus reverse transcriptase: Diverse functions as classical and emerging targets for antiviral intervention. Emerg Microbes Infect 2013;2:e56.

16. Minuk GY, Cohen AJ, Assy N, Moser M. Viral hepatitis and the surgeon. HPB (Oxford) 2005;7:56-64.

17. Akuta N, Kumada H. Influence of hepatitis B virus genotypes on the response to antiviral therapies. J Antimicrob Chemother 2005;55:139-42.

18. Fung SK, Lok AS. Hepatitis B virus genotypes: Do they play a role in the outcome of HBV infection? Hepatology 2004;40:790-2.

19. D'Souza R, Foster GR. Diagnosis and treatment of chronic hepatitis B. J R Soc Med 2004;97:318-21.

20. Badar N, Farooq U, Ali S, Nisar N, Abubakar M, Qureshi JA. A molecular approach for genotyping of hepatitis $b$ virus using restriction pattern analysis of s amplicon in Pakistan. Open J Med Microbiol 2012;2:16-23.

21. Malmström S, Berglin-Enquist I, Lindh M. Novel method for genotyping hepatitis $\mathrm{B}$ virus on the basis of taqMan real-time PCR. J Clin Microbiol 2010;48:1105-11.

22. Mello FC, Souto FJ, Nabuco LC, Villela-Nogueira CA, Coelho HS, Franz HC, et al. Hepatitis B virus genotypes circulating in Brazil: Molecular characterization of genotype F isolates. BMC Microbiol 2007;7:103.

23. Jutavijittum P, Jiviriyawat $Y$, Yousukh A, Kunachiwa W, Toriyama K. Genotypes of hepatitis B virus among voluntary blood donors in Northern Thailand. Hepatol Res 2006;35:263-6.

24. Alam MM, Zaidi SZ, Malik SA, Shaukat S, Naeem A, Sharif S, et al. Molecular epidemiology of hepatitis $\mathrm{B}$ virus genotypes in Pakistan. BMC Infect Dis 2007;7:115.

25. Noorali S, Hakim ST, McLean D, Kazmi SU, Bagasra O. Prevalence of hepatitis B virus genotype D in females in Karachi, Pakistan. J Infect Dev Ctries 2008;2:373-8.

26. Noorali S, Hakim ST, McLean D, Kazmi SU, Bagasra O. Prevalence of Hepatitis B virus genotype D in females in Karachi, Pakistan. The Journal of Infection in Developing Countries 2008;2:373-8.

27. Ding X, Gu H, Zhong ZH, Zilong X, Tran HT, Iwaki Y, et al. Molecular epidemiology of hepatitis viruses and genotypic distribution of hepatitis B and C viruses in Harbin, China. Jpn J Infect Dis 2003;56:19-22. 